\title{
UJI AKTIVITAS ANTIBAKTERI EKSTRAK ETANOL HERBA TUMBUHAN BALSEM (Polygala paniculata L.) TERHADAP BAKTERI Staphylococcus aureus DAN Escherichia coli
}

\section{Antibacterial Activity of Ethanol Extract of Herbal Balm (Polygala paniculata L.) against Staphylococcus aureus and Escherichia coli}

\author{
Hotnauli Nababan ${ }^{1}$, Helen Anjelina Simanjuntak ${ }^{1 *}$, Kasta Gurning1
}

1Sekolah Tinggi Ilmu Kesehatan (STIKes) Senior Medan, Program Studi Sarjana Farmasi, Jl. Jamin Ginting No. 13 KM 8,5 Padang Bulan, Medan, Indonesia.

KATA KUNCI KEYWORDS

ABSTRAK

ABSTRACT
Antibakteri, Ekstrak, Balsem (Polygala paniculata L.)

Antibacterial, Extract, Balm (Polygala paniculata L.)

Penyakit infeksi ialah penyakit yang disebabkan oleh masuk dan berkembangbiaknya mikroorganisme seperti bakteri. Tumbuhan balsem (Polygala paniculata L.) bermanfaat dalam menyembuhkan gonorrhoea, rematik dan menyembuhkan luka. Tujuan penelitian ini adalah untuk mengetahui aktivitas antibakteri dari ekstrak etanol tumbuhan balsem dan untuk mengetahui konsentrasi efektif dalam menghambat pertumbuhan bakteri Staphylococcus aureus dan Escherichia coli. Metode penelitian dilakukan dengan eksperimental, dan pengujian aktivitas antibakteri dilakukan dengan menggunakan metode difusi agar. Variasi konsentrasi ektrak terdiri dari 50\%, $25 \%, 12,5 \%, 6,25 \%$, Akuades sebagai kontrol negatif dan kloramfenikol sebagai kontrol positif. Hasil menunjukkan bahwa pada semua konsentrasi menunjukkan aktivitas antibakteri dengan katergori sedang.

Infectious diseases due to diseases caused by the entry and proliferation of microorganisms such as bacteria. Balm (Polygala paniculata L.) is useful in healing gonorrhea, rheumatism and wound healing. The purpose of this study was to study the antibacterial activity of ethanol extracts of balm plants and to determine the effective concentration in inhibiting the growth of Staphylococcus aureus and Escherichia coli. The research method was carried out experimentally, and testing for antibacterial activity was carried out using agar diffusion methods. Concentration variations consisted of $50 \%, 25 \%, 12.5 \%, 6.25 \%$, distilled water as negative control and chloramphenicol as positive control. The results showed that all results showed antibacterial activity with a medium category. 


\section{Pendahuluan}

Penyakit infeksi terjadi ketika interaksi dengan mikroba menyebabkan kerusakan pada tubuh dan kerusakan tersebut menimbulkan berbagai gejala dan tanda klinis. Mikroorganisme yang menyebabkan penyakit pada manusia disebut sebagai mikroorganisme patogen, salah satunya bakteri patogen (Nugroho et al., 2013), seperti Staphylococcus aureus dan Escherichia coli.

Bakteri Staphylococcus aureus merupakan bakteri gram positif yang memiliki habitat alami pada manusia yaitu pada kulit, mukosa hidung, mulut, dan usus besar, apabila sistem imun manusia dalam keadaan lemah maka bakteri ini dapat bersifat patogen yang dapat menyebabkan nanah, abses dan berbagai infeksi pirogen. Bakteri Escherichia coli merupakan bakteri gram negatif yang normal hidup di dalam usus, namun tidak menutup kemungkinan bakteri tersebut akan menjadi patogen apabila keluar dari habitatnya. Gejala-gejala infeksi yang disebabkan oleh bakteri ini biasanya berupa diare dan kram abdomen (Jawetz, 1996).

Obat tradisional sejak dulu memainkan peranan yang penting dalam menjaga kesehatan, mempertahankan stamina dan mengobati penyakit, oleh karena itu obat tradisional masih berakar kuat dalam kehidupan masyarakat hingga kini. Tumbuhan yang berkhasiat obat banyak sekali di sekitar kita. Ada yang berupa bumbu dapur, tanaman buah, tanaman hias dan tanaman sayur, selain itu juga ada tanaman liar yang tumbuh di sembarang tempat tanpa ada yang memperhatikan seperti tumbuhan balsem (Polygala paniculata L.) (Muhlisah, 2005).

Tumbuhan balsem (Polygala paniculata L). merupakan salah satu marga terbesar yang tergolong dalam suku Polygalaceae. Marga ini terdiri dari 500 jenis dan dapat ditemukan di daerah di daerah tropik, sub tropik, temperate dan di pegunungan di seluruh dunia kecuali Selandia Baru. Sebagian besar dari jenis tersebut tumbuh di daerah Amerika Tropis Tengah dan Selatan. Beberapa jenis Polygala L. yang dapat dimanfaatkan sebagai obat diantaranya adalah: Polygala chinensis L., Polygala paniculata L., Polygala polifolia Presl., dan Polygala sibirica L Khasiat dari tumbuhan banyak dimanfaatkan sebagai obat, akarnya dikenal mempunyai efek ekspektoran yang dipakai untuk mengobati batuk, asma dan brokhitis. Air rebusan digunakan sebagai obat gonorrhoea dan sakit rematik di bagian punggung, daunnya yang dihaluskan dapat digunakan untuk mengobati luka, namun penggunaannya harus dilakukan secara berhati-hati dikarenakan air atau getahnya dapat menyebabkan rasa perih apabila terkena mata (Valkenburg, 2001).

\section{Metode Penelitian}

\subsection{Lokasi dan Sampel Penelitian}

Penelitian ini dilakukan pada bulan Maret hingga bulan Mei 2019. Bertempat di Laboratorium Mikrobiologi, Program Studi Sarjana Farmasi, Sekolah Tinggi Ilmu Kesehatan (STIKes) Senior Medan.

Sampel tumbuhan balsem (Polygala paniculata L.) diperoleh dalam keadaan segar dari Kecamatan Parmonangan, Kabupaten Tapanuli Utara, kemudian diidentifikasi di Laboratorium Herbarium Medanense Universitas Sumatera Utara, dan dilakukan uji skrining fitokimia. 


\subsection{Isolasi Bakteri}

Isolat bakteri Staphylococcus aureus dan Escherichia coli diperoleh dari Laboratorium Farmasi, USU.

\subsection{Uji Aktivitas Antibakteri}

Sebanyak 28 gram media NA dilarutkan dalam $1000 \mathrm{ml}$ akuades dan dipanaskan sampai homogen. Kemudian media NA dituangkan cawan petri steril diamkan hingga memadat, diambil satu usap biakan bakteri yang sudah disesuaikan dengan standar McFarland, lalu digoreskan pada media NA yang telah memadat.

Penentuan aktivitas antibakteri dilakukan dengan metode difusi agar menggunakan kertas cakram (paper disc) berdiameter $6 \mathrm{~mm}$. Paper disc direndam selama \pm 15 menit dalam variasi konsentrasi ekstrak herba tumbuhan balsem dengan konsentrasi berbeda 50\%, 25\%, 12,5\% dan 6,25\%, serta akuades sebagai kontrol negatif dan kloramfenikol sebagai kontrol positif.

Paper disc hasil rendaman diletakkan pada media yang sudah berisi bakteri (Staphylococcus aureus dan Escherichia coli). Diinkubasi selama $1 \times 24$ jam pada suhu $37^{\circ} \mathrm{C}$. Dilakukan sebanyak tiga kali ulangan. Kemudian diamati dan dihitung diameter zona bening pada paper disc, sebagai zona hambat.

\section{Hasil}

\subsection{Skrining Fitokimia}

Hasil skrining fitokimia pada tumbuhan balsem (Polygala paniculata L.) dapat dilihat pada Tabel 1.

Tabel 1. Hasil Skrining Fitokimia

\begin{tabular}{llcc}
\hline No. & \multirow{2}{*}{ Metabolit Sekunder } & \multicolumn{2}{c}{ Skrining Fitokimia } \\
\cline { 3 - 4 } & & Simplisia & Ekstrak \\
\hline 1 & Flavonoid & Positif & Positif \\
2 & Saponin & Positif & Positif \\
3 & Tanin & Positif & Positif \\
4 & Alkaloid & Positif & Positif \\
5 & Triterpenoid/Steroid & Positif & Positif \\
\hline
\end{tabular}

Berdasarkan Tabel 1 diatas dapat dilihat bahwa tumbuhan balsem (Polygala paniculata L.) mengandung senyawa metabolit sekunder seperti flavonoid, saponin, tannin, alkaloid, dan triterpenoid/steroid.

Hal ini sejalan dengan penelitian (Sari, 2012 dalam Rijai, 2013) dengan menggunakan ekstrak etanol pekat. Dimana metabolit sekunder yang terdapat pada tumbuhan memiliki aktivitas biologis salah satunya sebagai antibakteri.

\subsection{Diameter Zona Hambat}

Hasil diameter zona hambat terhadap pertumbuhan bakteri dapat dilihat pada Tabel 2. 
Tabel 2. Hasil Diameter Zona Hambat Terhadap Pertumbuhan Bakteri Staphylococcus aureus dan Escherichia coli

\begin{tabular}{lccc}
\hline Variasi Sampel & \multicolumn{3}{c}{ Diameter Zona Hambat $(\mathbf{m m})$} \\
\cline { 2 - 4 } & Staphylococcus aureus & Escherichia coli & Kategori \\
\hline $50 \%$ & 9 & 9 & Sedang \\
$25 \%$ & 8,5 & 8,7 & Sedang \\
$12,5 \%$ & 7,5 & 8 & Sedang \\
$6,25 \%$ & 5,5 & 7 & Sedang \\
Kloramfenikol & 27,5 & 26,7 & Sangat Kuat \\
Akuades & 0 & 0 & Lemah \\
\hline
\end{tabular}

Berdasarkan Tabel 2 dapat dilihat bahwa ekstrak etanol tumbuhan balsem pada masing-masing konsentrasi menunjukkan aktivitas antibakteri dengan kategori sedang. Hasil menjelaskan bahwa ekstrak etanol tumbuhan balsem memiliki aktivitas antibakteri, hal ini disebabkan karena adanya senyawa metabolit sekunder yang berperan sebagai antibakteri seperti flavonoid, saponin, alkaloid, tannin, triterpenoid/steroid.

\section{Pembahasan}

Berdasarkan dari Tabel 1 dapat dilihat bahwa metabolit sekunder terdiri dari flavonoid, saponin, tannin, alkaloid, dan terpenoid/steroid. Metabolit tersebut memiliki aktivitas sebagai antibakteri.

Mekanisme kerja flavonoid memberikan efek bakteriolitik, menghambat sintesis protein, sintesis DNA, RNA dan merusak permeabilitas membran sel (Dzoyem et al. 2013). Menurut Wu et al (2013), flavonoid memiliki aktivitas sebagai antibakteri karena kemampuan flavonoid untuk berinteraksi dengan membran sel dan mempengaruhi bioaktivitas membran sel dan telah dilaporkan bahwa flavonoid mampu mengurangi fluiditas membran sel bakteri yang berhubungan langsung dengan kerusakan membran sitoplasma atau kerusakan tidak langsung melalui autolysis/ melemahnya dinding sel dan akibatnya terjadi lisis osmotic.

Mekanisme kerja saponin sebagai antibakteri dapat menyebabkan lisis dinding sel bakteri dan kebocoran AKP (Alkaline Phosphate) peningkatan konsentrasi saponin menyebabkan protein larut, menyebabkan interseluler senyawa untuk berdifusi melalui membran luar dan dinding sel, sehingga sitoplasma bocor keluar dari sel dan menyebabkan kematian sel (Khan, et al. 2018). Tannin adalah polifenol yang larut dalam air yang dapat mengendapkan protein. Tannin telah dilaporkan dapat mencegah perkembangan mikroorganisme dengan mengendapkan protein mikroba dan membuat protein nutrisi tidak tersedia untuk bakteri (Prasad et al., 2008). Tannin berperan sebagai antimikroba dengan kurang zat besi, ikatan hydrogen atau interaksi spesifik dengan protein vital seperti enzim dalam sel mikroba. Herbal yang memiliki komponen tannin bersifat astringen dan digunakan dalam pengobatan gangguan usus seperti diare dan disenteri (Dharmananda, 2003). 
Mekanisme kerja alkaloid dalam mengganggu komponen penyusun peptidoglikan pada dinding sel bakteri dan sebagai akselerator dalam enzim topoisomerase dalam penghambat DNA sel bakteri (Wu, et al. 2013 dalam Simanjuntak, 2020).

Mekanisme kerja triterpenoid memiliki aktivitas antimikroba yang luas terhadap bakteri, ragi dan jamur berfilamen. Triterpenoid bersifat sebagai antimikroba karena dapat merusak membran sel ragi atau kerusakan sintesis membran lipid yang mengakibatkan permeabilitas membran sehingga terjadi kebocoran komponen sel (Haraguchi et al, 1999).

\section{Kesimpulan}

Aktivitas antibakteri dari ekstrak etanol tumbuhan balsem (Polygala paniculata L.) memiliki aktivitas antibakteri dengan kategori sedang pada semua konsentrasi.

\section{Daftar Pustaka}

Dharmananda, S. 2003. Gallnut and The Uses of Tannins in Chinese Medicine, In: Proceedings of Institute For Traditional Medicine. Portland. Oregon.

Dzoyem JP, Hiroshi H, Barthelemy N, Bonaventure TN, Kazuhisa S. Antimicrobial Action Mechanism of Flavonoids From Dorstenia Spesies. 2013. Drug Discoveries \& Therapeutic. 7(2): 66-72.

Haraguchi, H., Shintaro K., Shiho O., Muhammad H and Kozo Shibata. 1999. Antimicrobial Triterpenes From Illex integra and The Mechanisme of Antifungal Action. Phytotherapy Research. 13: 151 - 156.

Jawetz, Ernest., L., Joseph, Melnick, dan Erward, A. 1996. Mikrobiologi Kedokteran. Jakarta : EG. 354.

Khan MI, Abdulatef A, Jin HS, Jun SB, Min YK,Jong DK. 2018. Green Tea Seed Isolated Saponins Exerts Antibacterial Effects Against Various Strains of Gram Positive and Gram Negative Bacteria A Comprehensive Study In Vitro and In Vivo. Evidence-Based Complementary and Alternative Medicine.1-12.

Muhlisah F. 2005, Tanaman Obat Keluarga. Penebar Swadaya, Jakarta. 34.

Nugroho AW, translator. Brooks GF, Carroll KC, Butel JS, Morse SA, Mietzner TA. 2013. Mikrobiologi Kedokteran Jawetz, Melnick, \& Adelberg. Ed. 25. Jakarta: Penerbit Buku Kedokteran EGC. p. 55-86.

Prasad, N.R., Viswanathan S., Devi, J.R., Nayak V. Swetha, C.V. Archana, B.R., Parathasarathy, N. and Rajkumar J. 2008. Preliminary Phytochemical 
Screening and Antimicrobial Activity of Samanea saman. Journal of Medicinal Plants Reseacrh. 2(10): 268 - 270.

Rijai Laoude. 2013. Potensi Herba Tumbuhan balsem (Polygala paniculata Linn) Sebagai Sumber Bahan Farmasi Potensial. J. Trop. Pharm. Chem. Vol 2 (2): 105 112.

Sari, W. 2012. Kandungan Metabolit Sekunder dan Potensi Sitotoksik Ekstrak Herba Tumbuhan Balsem (P. paniculata). Skripsi. Fakultas Farmasi. UNMUL. Samarinda.

Simanjuntak, HA. 2020. Antibacterial Activity of Ethanolic Extract of Kitolod (Hippobroma longiflora) Leaf Against Staphylococcus aureus and Salmonella typhi. Asian Journal of Pharmaceutical Research and Development. 8(1): 52-54.

Valkenburg, van, J.L.C.H., \& N Bunyapraphatsara (editor). 2001. Plant Resources of South East Asia; Medicinal \& Poisonous Plants (2). (PROSEA Publication Office. Indonesia dan Backhuys Publisher, Leiden). The Netherlands. 156-160

Wu T, Mengying H, Xixi Z, Ying Z, Tianfu Q, Siyi P, Xiaoyun X. 2013. A Structure Activity Relationship Study of Flavonoids As Inhibitors of E. coli By Membran Interaction Effect. Biochimica et Biophysica Acta.2751-6. 